Leven met een dwangstoornis 
De boeken in de reeks Van A tot ggZ beschrijven niet alleen oorzaak, verloop en behandeling van de onderhavige problemen, maar geven ook antwoord op de vraag hoe men met het probleem om moet gaan. Door de prettig leesbare combinatie van beschouwingen, cartoons en citaten zijn de boeken niet alleen geschikt voor vertegenwoordigers van patiëntenverenigingen, behandelaren en mantelzorgers, maar vooral ook voor de cliënten zelf en de mensen in hun directe omgeving.

De reeks staat onder redactie van:

- $\quad$ Fred Sterk, psycholoog-psychotherapeut, werkzaam bij CAP Den Haag, centrum coor arbeid en psyche, tevens docent in het postacademisch onderwijs

- $\quad$ Sjoerd Swaen, psycholoog-psychotherapeut, werkzaam bij PsyQ. psycho-medische programma's te Den Haag, afdeling angststoornissen, tevens supervisor en docent in het post-academisch onderwijs

- Jenny Swart, fondsredacteur, uitgeverij Bohn Stafleu van Loghum

Voor een actueel overzicht van de reeds verschenen titels zie www.a-ggz.nl. 


\section{Leven met een dwangstoornis}

Fred Sterk en Sjoerd Swaen

Bohn Stafleu Van Loghum

Houten/Diegem 2001 
(c) 2001 Bohn Stafleu van Loghum, Houten

Alle rechten voorbehouden. Niets uit deze uitgave mag worden verveelvoudigd, opgeslagen in een geautomatiseerd gegevensbestand, of openbaar gemaakt, in enige vorm of op enige wijze, hetzij elektronisch, mechanisch, door fotokopieën, opnamen, of enig andere manier, zonder voorafgaande schriftelijke toestemming van de uitgever.

Voor zover het maken van kopieën uit deze uitgave is toegestaan op grond van artikel 16b Auteurswet $1912 \mathrm{j}^{\circ}$ het Besluit van 20 juni 1974, Stb. 351, zoals gewijzigd bij Besluit van 23 augustus 1985, Stb. 471 en artikel 17 Auteurswet 1912, dient men de daarvoor wettelijk verschuldigde vergoedingen te voldoen aan de Stichting Reprorecht (Postbus 3051, $2130 \mathrm{~KB}$ Hoofddorp). Voor het overnemen van (een) gedeelte(n) uit deze uitgave in bloemlezingen, readers en andere compilatiewerken (artikel 16 Auteurswet 1912) dient men zich tot de uitgever te wenden.

ISBN 9031335622

NUGI 777

Ontwerp omslag: p3, Huizen

Bohn Stafleu van Loghum

Het Spoor 2

Postbus 246

3990 GA Houten

www.bsl.nl
Distributeur in België:

Standaard Uitgeverij

Mechelsesteenweg 203

2018 Antwerpen

www.standaarduitgeverij.be 


\section{Voorwoord}

In dit boek komen de oorzaken, behandelingsmogelijkheden en zelfhulptechnieken voor de dwangstoornis aan de orde.

De dwangstoornis komt vaker voor dan eerst gedacht werd: ongeveer $2,6 \%$ van de totale bevolking heeft een dwangstoornis. Het gaat hierbij om serieuze klachten die zeer beangstigend kunnen zijn. Op de langere termijn kan een onbehandelde dwangstoornis tot allerlei extra problemen leiden: sociaal isolement en ernstige belemmeringen in het gezins- en beroepsleven.

We hebben geprobeerd om de kennis die er op dit moment is over de dwangstoornis zo toegankelijk mogelijk weer te geven. Hoe meer je over deze stoornis weet, hoe makkelijker het is maatregelen te nemen die nodig zijn om een zo plezierig mogelijk leven te leiden.

Heb je opmerkingen over het boek, of heb je nieuwe, interessante informatie, laat dit dan aan de uitgever weten. Bij een volgende druk zal daar dankbaar gebruik van gemaakt worden.

Wij willen de volgende mensen bedanken die ons met adviezen, intervisie en supervisie de afgelopen jaren gestimuleerd hebben: onze collega's en cliënten bij Altrecht in Utrecht, Parnassia PMC in Den Haag en 
de Stichting Fobieclub Nederland in Driebergen, met name Josine van Hamersveld.

Daphne Dotsch en Jenny Swart van uitgeverij Bohn Stafleu Van Loghum bedanken wij voor hun inzet, visie en vooral geduld; Warnyta Koedijk van uitgeverij Kosmos Z\&K voor haar medewerking; en ten slotte ons mede-redactielid van de 'A-ggZ-reeks', Joke Kragten, voor haar waardevol commentaar op het manuscript.

Fred Sterk en Sjoerd Swaen

Utrecht, augustus 2001 


\section{Inhoud}

Voorwoord

$1 \quad$ Wat is er met me aan de hand?

Typerend beeld van de dwangstoornis $\quad 11$

$\begin{array}{ll}\text { Symptomen } & 13\end{array}$

Wat zijn obsessies? $\quad 14$

Wat zijn compulsies? $\quad 17$

Vroege en late symptomen $\quad 18$

$\begin{array}{ll}\text { Diagnostiek } & 21\end{array}$

Obsessief-compulsieve stoornis $\quad 21$

Geen dwangstoornis $\quad 26$

Het verschil tussen dwang en drang $\quad 27$

Samenvatting $\quad 28$

$2 \quad$ Hoe heeft het zover kunnen komen? 31

Mogelijke oorzaken van de dwangstoornis en andere

angststoornissen 32

Langetermijnoorzaken $\quad 33$

Biologische oorzaken $\quad 35$

Kortetermijnoorzaken $\quad 36$

Oorzaken die de dwangstoornis instandhouden $\quad 37$

Samenvatting $\quad 42$ 
Een onbehandelde dwangstoornis $\quad 43$

Dwanggedrag dwingt anderen mee te doen $\quad 46$

Een dwangstoornis kan riskante vormen aannemen $\quad 48$

Behandeling van de dwangstoornis $\quad 48$

Motivatie en behandeling $\quad 50$

Samenvatting $\quad 55$

$4 \quad$ Wat betekent een en ander voor mijn omgeving? 57

Macht en onmacht van de omgeving $\quad 58$

De veiligheidspersoon als hulp bij het oefenen $\quad 60$

Informeer anderen over de klacht $\quad 64$

Grenzen stellen $\quad 66$

$\begin{array}{ll}\text { Samenvatting } & 70\end{array}$

$5 \quad$ Welke behandelingen bestaan er?

Lichamelijke angstbeheersing $\quad 75$

Medicatie $\quad 75$

Ademhalingsoefeningen $\quad 78$

$\begin{array}{ll}\text { Ontspanningsoefeningen } & 79\end{array}$

Geestelijke angstbeheersing $\quad 80$

Het aanpakken van rampgedachten $\quad 80$

Kijken door een dwangbril? $\quad 81$

Het uitdagen en veranderen van rampgedachten $\quad 85$

Niveaus van denken en waarnemen $\quad 89$

Positieve zelfinstructie en bibliotherapie $\quad 90$

$\begin{array}{ll}\text { Gedragsmatige angstbeheersing } & 92\end{array}$

Geleidelijk aan oefenen met het achterwege laten

van dwanggedrag $\quad 92$

Niet toegeven $\quad 93$ 
$\begin{array}{ll}\text { Valkuilen } & 94\end{array}$

Oefenen met het stappenplan $\quad 98$

$\begin{array}{ll}\text { Samenvatting } & 103\end{array}$

$6 \quad$ Hoe kan ik de draad weer oppakken? 105

Stichting Fobieclub Nederland 105

Therapie en realistische verwachtingen $\quad 107$

Wat kun je direct zelf doen? 108

Ademhalings- en ontspanningsoefeningen 108

Experimenten en vragen 112

Terugvalpreventie 114

Wat als niets helpt? 117

Ambulante, deeltijd- of klinische behandeling? 117

Andere therapievormen 118

Alternatieve hulpverlening $\quad 119$

$\begin{array}{ll}\text { Samenvatting } & 120\end{array}$

$7 \quad$ Adressen en literatuur 121

Specifiek voor mensen met angststoornissen $\quad 121$

Algemeen 122

Internet 123

Aanbevolen (zelfhulp)boeken 124

Voor dit boek geraadpleegde literatuur $\quad 124$

$\begin{array}{ll}\text { Over de auteurs } & 127\end{array}$ 
